\title{
Journal of Dairy Science Volume 100 Special Issue: Introduction
}

\author{
John P. McNamara*1,2 and Matthew C. Lucyt ${ }^{3}$ \\ ${ }^{*}$ Department of Animal Sciences (professor emeritus), Washington State University, and McNamara Research in Agriculture Firm, Pullman, \\ WA 99163 \\ †Division of Animal Sciences, University of Missouri, Columbia 65211
}

Humans have used cattle for food, power, fertilizer, clothing, and medicines for at least 10,000 years. The domestication of cattle allowed early humans to settle in one location or to move while maintaining an adequate food supply. As humans migrated around the planet, they took cattle with them. It is not by chance that cattle became and continue to be symbols and items of wealth and power in many cultures and regions. The ability to find and manage pasture, to store dried forages and grains, to implement systems for breeding, and to harvest both milk and meat sustainably were key in the advancement of civilizations that depended on cattle for food.

In the last 3 centuries, humankind developed sufficient technology for scientific investigation and adequate "leisure time" for detailed studies of cattle as a food source. By the middle of the 19th century, the urbanization of civilization proceeded to the point that greater efficiency of food production was needed. The cow stood ready to produce. Early empirically based genetic selection, improved nutrition, "rapid transit" along rail lines, and finally the development of refrigeration and sanitation procedures formed the basis for the nascent dairy industry. The dairy farmer took a leading role supplying food for hundreds of millions and then billions of people worldwide. Scientists initiated a widespread and systematic study of the basic science behind the production and processing of milk. The practical application of scientific knowledge and new technology led to an abundant supply of nutritious food derived from milk that was biologically efficient and environmentally sustainable.

In 1862, President Lincoln and the United States Congress recognized the importance of agricultural research, practice, and education and passed the Morrill Act, "An Act donating Public Lands to the several States and Territories which may provide Colleges for the Benefit of Agriculture and the Mechanic Arts."

Received September 24, 2017.

Accepted September 25, 2017.

${ }^{1}$ Corresponding author: mcnamara@wsu.edu

${ }^{2}$ Guest editor, Volume 100 special issue.

${ }^{3}$ Editor-in-chief, Journal of Dairy Science.
Soon, many states' colleges had departments of animal husbandry and dairy husbandry, studying the production and processing of food. The Hatch Act of 1887 added "... agricultural experiment stations in connection with the colleges established in the several States..." Several cheese schools were established for the safe and effective production of cheese for transport to urban populations and storage when effective refrigeration was not in place.

During this time, colleges and research stations were joined by industry people who championed modern dairy production standards. W. D. Hoard was clearly a prominent leader in these endeavors. Hoard noted, "The cow is the foster mother of the human race. From the day of the ancient Hindoo to this time have the thoughts of men turned to this kindly and beneficent creature as one of the chief and sustaining forces of human life." Acting as a private citizen and governor of Wisconsin, W. D. Hoard encouraged, planned, and funded what became the basis of modern dairy production practices. Included in his efforts were cow feeding and housing standards and the beginning of genetic selection standards, including the forerunner of the modern Dairy Herd Improvement Association (DHIA) program. Standards for production and processing of alfalfa for feed were developed, as were standards for milk to detect and prevent adulteration. He fought to protect dairy products through his support of the "Oleomargarine Act." Disease was a priority, as Hoard led a 50-year effort to eradicate tuberculosis from the national dairy herd. Education of the farmer was central to Hoard's philosophy for a successful dairy industry. In his speech in the early 1900s, he wrote, "[Wisconsin State Dairy Association] has held steadily to the one purpose of promoting dairy knowledge and improved dairy cattle... Make the farmer an intelligent, reading, thinking dairyman and all other material results will follow as supply follows demand" (Hoard Library; https://www.wisconsinhistory.org/turningpoints/ search.asp?id=973).

By 1907, the need for organized support and communication of the dairy sciences across the United States resulted in the founding of the Official Dairy Instructors' Association. In his 1913 presidential ad- 
dress to the association, Julius H. Frandsen, professor of animal husbandry and dairy husbandry and head of the department, University of Massachusetts, wrote

"In order that the association may accomplish the great tasks that lie before it, it should have the hearty support of all who are engaged in the various instructional and investigational lines of dairy work. In my estimation this can best be accomplished by some method which will give the association more prominence and publicity than it has enjoyed in the past. . . In my estimation, a journal published by our Association, either quarterly or monthly, would be of almost as great service to its members. It would give the Association an opportunity to publish committee reports, outlines for courses of study, and new official methods without needless delay. It would also provide for the publication of such original data as the members of the Society may care to contribute immediately upon its completion. It would also afford an excellent opportunity for the publication of such experimental work and observations as may be of interest to all engaged in this line of work, but of such nature that it may not be desirable to publish in bulletin form."

Within 4 years, the first issue of the Journal of Dairy Science was published, with Professor Frandsen as the editor-in-chief. He wrote in the opening announcement (Frandsen, 1917), "The American Dairy Science Association, formerly the Official Dairy Instructors' Association, has established THE JOURNAL OF DAIRY SCIENCE as the official organ of the Association and as a medium for the discussion of general and technical problems relating to the science of dairying, which confront the worker in every field of this important industry."

There were about 6.4 million farms and just under 100 million people in the United States when Frandsen wrote these words. Most farms had at least one cow, and about 3 million farms reported being primarily a dairy farm, with almost 20 million cows in the United States. The oldest land-grant college was barely 50 years old and many were only 20 to 30 years old with small enrollments. Nevertheless, a massive increase in scientific research and practical application to improve the human condition was beginning. As the population and economy expanded, departments of dairy husbandry were expanded from the old cheese schools and new ones were created, along with departments of animal and poultry husbandry in many states.

The number of dairy farms is in the United States is now approximately 40,000, with approximately 9 million dairy cows. Total production per cow in the United States has increased 4- to 5-fold since the first issue of the Journal of Dairy Science was published. The US trends in cow numbers, farms, and production are mirrored in other countries with modern production practices. Throughout the last 100 years, the Journal of Dairy Science has been, and remains, a running record of scientific and technological advancement in dairy production and science. Each issue, volume, and decade built on the last to answer relevant scientific questions and to report developments and technological advancements. In 2016, the journal published more than 700 articles and 10,000 pages from more than 1,000 authors and co-authors from all over the world. Topics included cheese quality, gene transcription in the mammary gland, the effect of milking parlor activity on milk production and quality, and the improvement of animal comfort and welfare. Without doubt, the original vision of J. H. Frandsen has been fulfilled.

This special issue represents our attempt to summarize and highlight 100 years of scientific and technical progress in dairy science. It was made possible through the financial support of the ADSA Foundation. Thirty separate but related papers, with 1,000 unique references, provide the dedicated reader an opportunity to learn where we are now and how we got here. Included in each article is a timeline of the major findings in each area. This series of papers can be used by anyone interested in the role that scientific research and technological advancement has played in efforts to make a safe and plentiful food supply for a growing population.

\section{REFERENCES}

Frandsen, J. H. 1917. Announcement. J. Dairy Sci. 1:1-3. https://doi .org/10.3168/jds.S0022-0302(17)94355-3. 